\title{
SUSTAINABLE URBAN TRANSPORT PLANNING
}

Melania R. Boitor, Phd student, Assistant professor, Technical University of Cluj-Napoca, e-mail: Melania.BOITOR@infra.utcluj.ro

Dago Antov, Phd, Professor, Technical University of Tallinn, e-mail: dago.antov@ttu.ee

Mihai Iliescu, Phd, Professor, Technical University of Cluj-Napoca, e-mail: Mihai.Iliescu@ infra.utcluj.ro

Imre Antso, Phd student, Technical University of Tallinn, e-mail: imre.antso@ttu.ee

Roland Mäe, Phd student, Technical University of Tallinn, e-mail: Roland.Mae@ttu.ee

\section{Abstract}

Environmental protection has become a common issue in every area, but extremely important for the domains which deal with intensive energy consumption as it is the case of the transportation. Achieving the sustainable cities on the other hand, is also focused on the protection of the environment in order to provide a higher quality of life for the population. Therefore it is considered that by improving the urban transportation planning additional benefits could be provided for both the environment and the sustainable development of the cities. One possibility is to supplement the traditionally land-use plans with the transportrelated zones analysis, where the city is divided in public transport, pedestrian and caroriented zones. Analyzing the transport-related zones of a city is important as it provides additional information in the assessment of the development trend. The process of zoning was conducted for the city of Cluj-Napoca, Romania. In this paper, the outcome of the zoning was analyzed for a more comprehensive review of the urban transport in order to attain a sustainable-oriented approach of the urban area development.

Keywords: transport planning, travel-related zones, modal split.

\section{INTRODUCTION}

Accommodating the ongoing development of the urban area in a sustainable manner represents a challenge for the urban planners, which is directly connected to the urban transportation. Whilst it is considered the core of the development, the transport is a high energy consumer. Furthermore, the transport has adverse environmental and non-environmental impacts, which affects the urban structure and society, such as emissions, noise, congestion, accidents, urban sprawl and suburbanization, automobile mobility and reduced accessibility etc. In order to stop the urban sprawl and suburbanization planners have to provide a different approach in the urban development process with a 
more sustainable orientation. In this direction a systemic planning approach with a more comprehensive analysis of the effects which the solutions provided in the planning process produce on the whole urban system is needed. For example it was proved that the more compact and the mixed land-use cities have less energy consumption and reduced impact on the environment. Thus providing an integrated land-use and transport planning and policy is one possibility of redressing the urban sustainability from the local level [5].

\section{THE SYSTEMIC EFFECTS OF THE URBAN TRANSPORT}

The traditional planning, with its car-oriented approach, allows car traffic almost everywhere in the urban area and provides as much road infrastructure as possible. The automobile became the most used mode of transport in the urban area. This led to increased traffic and congestion. Congestion is treated in the traditional planning by providing additional infrastructure. When the changes in the settlement structure are made they encouraged more motorized traffic, especially at the city border [1]. Thus an artificial demand for long distance trips is created and it leads to severe adverse effects such as:

- the opportunities for the local scale is damaged, both the communities and the local economy are destroyed

- more energy consumption and pollution, thus more environmental and social negative impacts

- the automobile mobility and reduced accessibility

- cities become much less compact

- vicious and often irreversible cycles of sprawl are encountered.

As a conclusion building more and better infrastructure has more adverse effects than solve the transport problems and does not provide time saving, enhanced mobility or any other benefits. The mobility remains constant in the transport system since it is purpose-related, either considering the intra-urban and the inter-urban trips, or when considering all modes of transport. Furthermore the car usage is favored by the optimization of parking on an individual level [7]. Shifting the modal choice from private car to other modes is one of the possibilities to reduce the negative effects of transportation on the community, urban structure, and environment. 


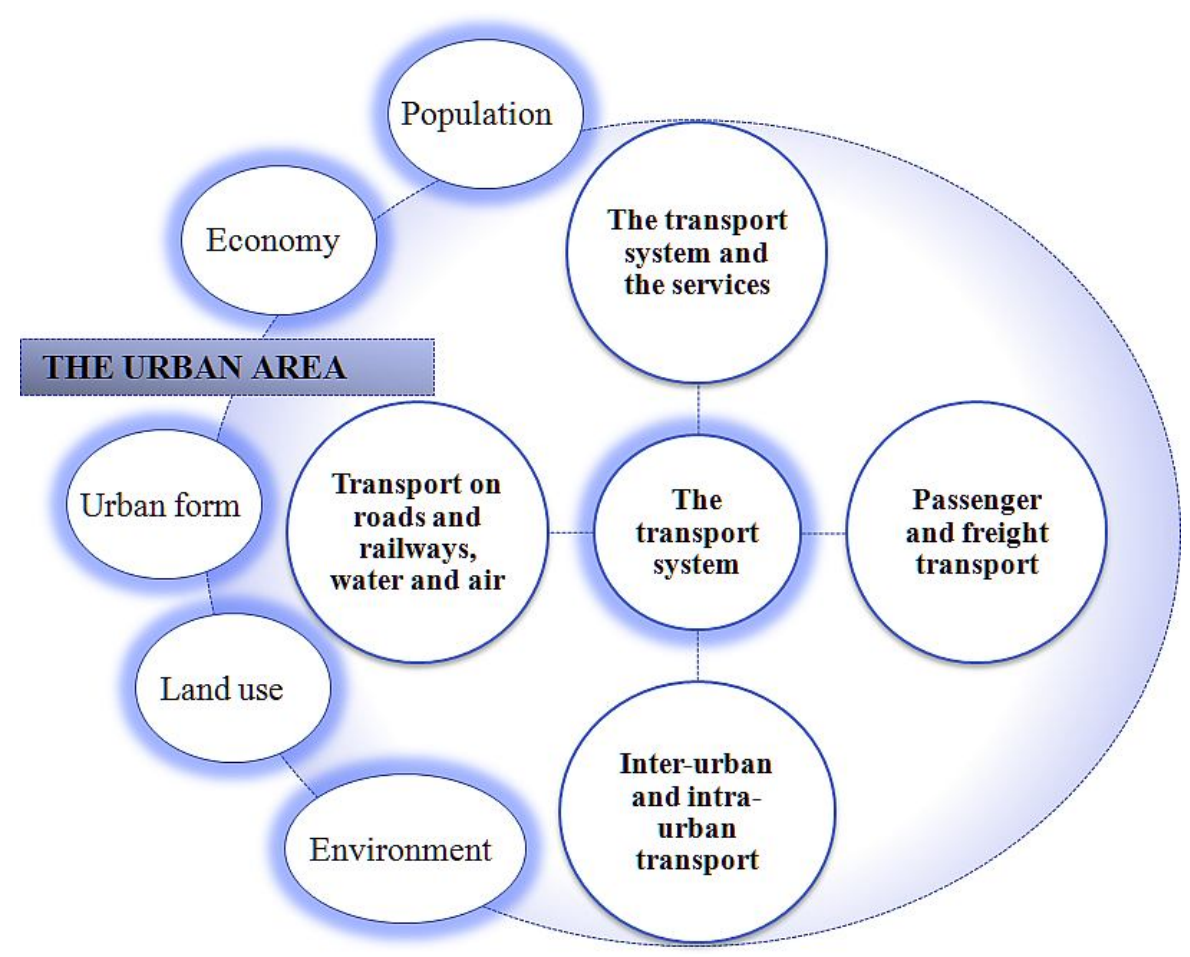

Figure 1. The urban area and transport system

Therefore a reconsideration of all interconnected links of the transport system is needed in order to create an effective urban fabric: population density as users, car density and usage, public transport services, walking and cycling conditions. Furthermore the social aspects of the community regarding the housing, the habits, the culture and businesses also have to be considered. As a consequence the planners need to provide new concepts and methods for a more comprehensive analysis of the urban area in order to find the possibilities to retain the residents in the city and stop the urban sprawl and suburbanization.

\section{INTEGRATED PLANNING, THE TRAVEL-RELATED ZONES.}

A new integrated planning method has been recently developed by means of research analysis by Ristimäki et al [9]. The method considers the connections between urban form, the land use and the public transport services availability and divides the urban area into travel-related zones - pedestrian, public transport and car-oriented zones. Aspects as the population density, public transport supply and travel demand, are studied for the assessment of the urban area and transport development. The data is assigned on the grid of 250x250 m cells which provides the opportunity for detailed planning with the respect for smaller urban areas and their population. The method was applied in 
Finland for all the urban areas with more than 15,000 inhabitants, and represents now a successful tool in planning, urban design and development approaches and political decision-making. The zoning is an integrated planning process which also provides the systemic analysis of the effects of the transportation on the society, environment and urban structure. For example, in the case of Helsinki metropolitan area, the share of different modes and energy consumption were determined. The car-mileage per person and the emissions generated by the passenger traffic were also assessed. Thus it represents a real sustainable-oriented urban planning tool.

The zoning process was also developed for the city of Cluj-Napoca with the aim of assessing the accessibility to transportation in smaller areas such as the travelrelated zones and to provide a better accessibility in order to improve the quality of life of the citizens [2]. Furthermore, in this paper is analyzed the possibility to improve the mobility to the sustainable or more benign modes. The modal choices and possibilities to shift from car use are also analyzed as opportunities to attain the sustainable urban transport planning for the city of Cluj-Napoca.

\section{THE CARACTERISTICS OF THE CLUJ-NAPOCA URBAN AREA}

Cluj-Napoca is the second major city in Romania. It is an important academic, administrative, cultural, and business center in the country. The planning process and policies hierarchy for Cluj-Napoca urban development apply from the national, regional, county, metropolitan to local level, all converging with the European vision and plans. The administrative area of ClujNapoca is $179.5 \mathrm{~km}^{2}$. The urban form of the city is single-cored and radialshaped, spreading out from the city centre onto the surrounding hills. The city centre is a mixed-use area. There are 15 major districts directly connected with the city centre, with $80 \%$ of the dwellings accommodated as collective buildings, within a compact urban tissue [4]. There are other 6 major new built residential areas, developed in isolation from the city centre as dispersed, medium and low density areas. The spread out development trend of the new housing areas is illustrated in figure 2 . 
ROMANIAN JOURNAL

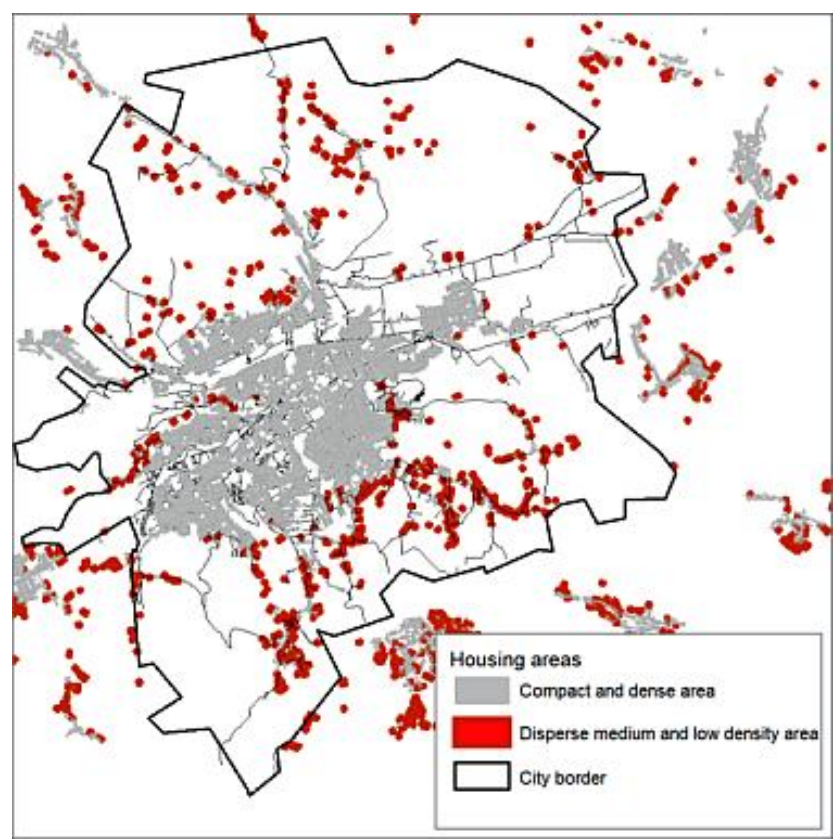

Figure 2. The new housing area in Cluj-Napoca

Population density is a defining characteristic for the urban areas and it is the most dynamic element in the planning process. The population is about 314,500 people and the density is $1752 \mathrm{inh} / \mathrm{km}^{2}$. The population density in small scale clusters is also available (figure 3). There are also on average 100,000 students registered every year who are considered as a temporary population segment.

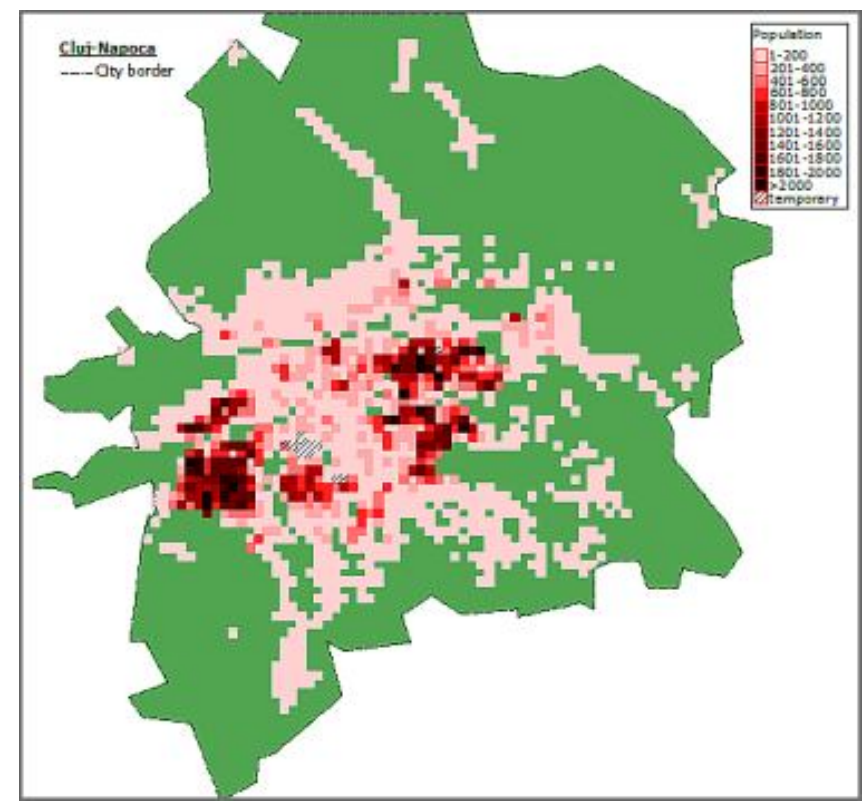

Figure 3. The population density in small scale clusters in Cluj-Napoca [3] 
The inter-urban transportation system includes air connections, roads and railways. The street network has a length of $662 \mathrm{~km}$, the majority having at least one way sidewalks, from which $80 \%$ are considered to offer proper conditions for the pedestrian use. The local government also began to develop a cycling tradition in the city with the project Clujul Mobil (The Mobile Cluj). The motorization level is 322 cars per 1000 inhabitants. The modal share is presented in figure 4 and a comparison to other Romanian cities is illustrated in figure $5[6]$.

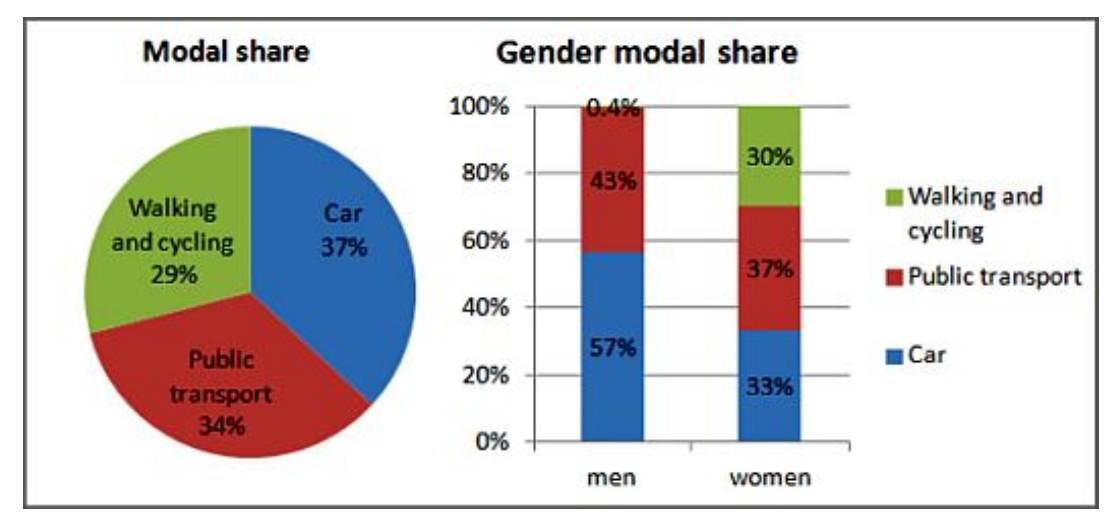

Figure 4. The modal split in Cluj-Napoca, 2013 [2]

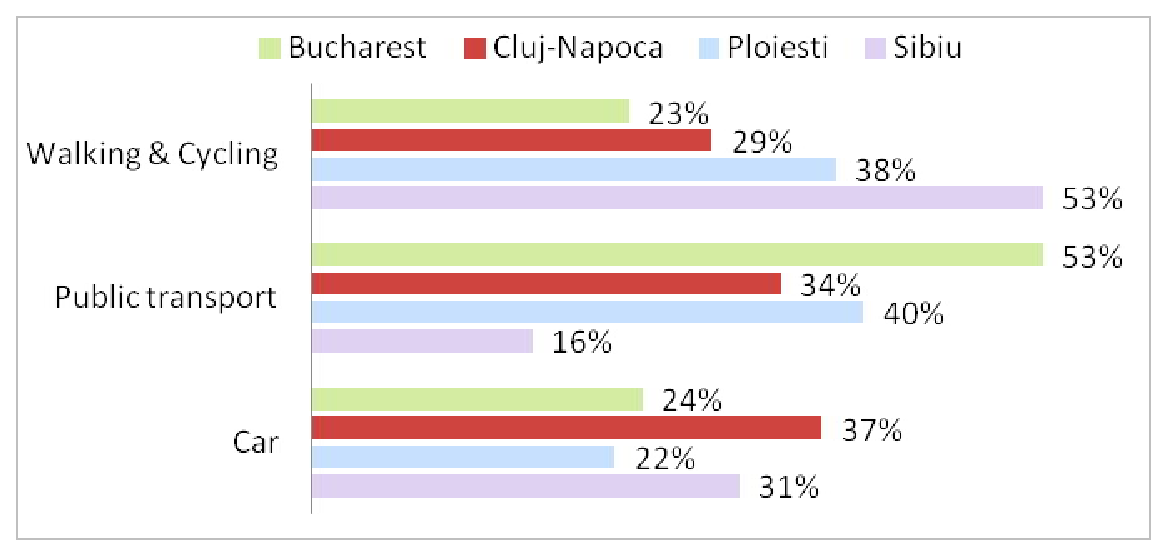

Figure 5. The modal split in the Romanian cities

The car is the most used mode of transport in Cluj-Napoca with a share of $37 \%$ in the modal split. The public transportation is second with a share of $34 \%$. The urban public transport system is organized by the local government and the services are provided by one subordinated company [8]. It includes 3 tram lines, 6 trolleybus lines, 37 bus lines and several dedicated minibuses for the disabled 
people. The public transport is the main mode of transport for the educationrelated trips. There are also some 3000 taxies registered in the city.

The emissions level is higher than the nationally accepted limits and affects a large area of the city mainly around the major transport corridors and industrial sites with serious implication on people health and environment. Another major problem is the lack of green areas and furthermore their transformation into spontaneously parking lots. Noise and air pollution are perceived as major problems encountered mainly around the transport corridors.

\section{THE ANALYSIS OF THE CLUJ-NAPOCA URBAN AREA}

The zoning method was applied for the city of Cluj-Napoca on a statistical grid of $250 \times 250 \mathrm{~m}$ cells. The methodology included the analysis of the following data: the population density in small clusters, the urban form, the land-use, especially the location of housing in connection with the services and institutions, the public transport stops' locations and headways, the travel demand per modes. After the data were analyzed they were assigned to the statistical grid. According to the zoning criteria, the urban area was divided into travel-related zones: pedestrian, public transport and car-oriented, with detailed characteristics in table 1. The graphic outcome is illustrated in figure 6.

Table 1. The zoning outcome - the zones' characteristics

\begin{tabular}{|c|c|c|c|c|}
\hline Travel zone & Characteristics & Area & Population & Modes \\
\hline $\begin{array}{l}\text { Pedestrian } \\
\text { zone }\end{array}$ & $\begin{array}{l}\text { clusters within } 2 \mathrm{~km} \\
\text { of the city centre, } \\
\text { with high-quality } \\
\text { public transport } \\
\text { services, accessibility } \\
\text { to all modes }\end{array}$ & $1 \%$ & $2 \%$ & $\begin{array}{l}\checkmark \text { walking } \\
\text { and cycling } \\
\checkmark \text { public transport } \\
\checkmark \text { car }\end{array}$ \\
\hline \multirow{2}{*}{$\begin{array}{l}\text { Public } \\
\text { transport } \\
\text { zones } \\
\text { 1) intensive } \\
\text { 2) good } \\
\end{array}$} & \multirow{2}{*}{$\begin{array}{l}\text { clusters defined } \\
\text { based on the peak } \\
\text { period headway } \\
\text { services and walking } \\
\text { distance to the stops }\end{array}$} & 1) $12 \%$ & $45.3 \%$ & \multirow{2}{*}{$\begin{array}{l}\checkmark \text { walking } \\
\text { and cycling } \\
\checkmark \text { public transport } \\
\checkmark \text { car }\end{array}$} \\
\hline & & 2) $8 \%$ & $12.3 \%$ & \\
\hline \begin{tabular}{|l|} 
Car- \\
oriented \\
zones
\end{tabular} & $\begin{array}{l}\text { clusters characterized } \\
\text { by the intense share } \\
\text { of the personal } \\
\text { automobile mode }\end{array}$ & $79 \%$ & $40.4 \%$ & $\checkmark$ car \\
\hline
\end{tabular}




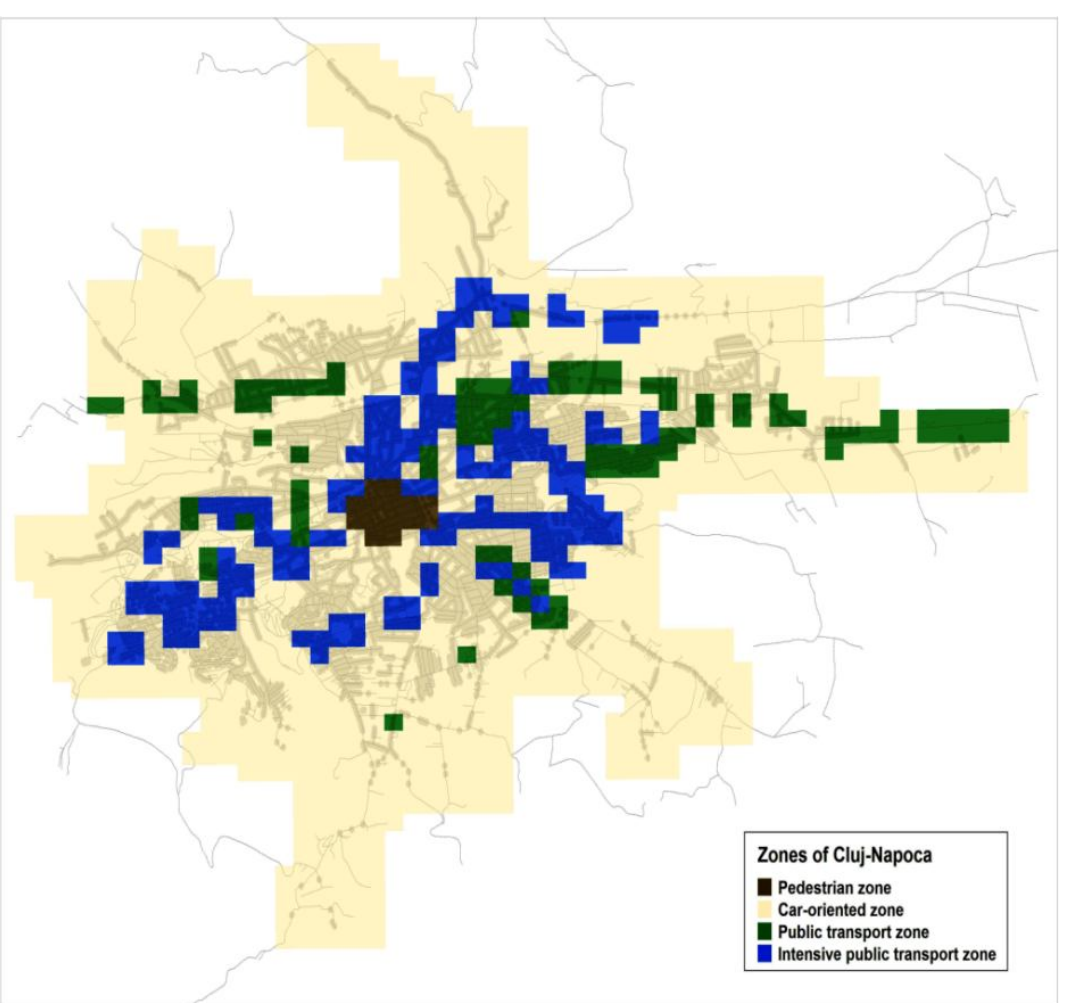

Figure 6. The travel-related zones in Cluj-Napoca [2]

The pedestrian zone (brown) corresponds to roughly the historic area. The main corridors of the public transport, including both intensive (blue) and good (green) public transport cells spread on the main axis of the urban form. The caroriented zones (yellow) are surrounding the public transport and pedestrian cells and highlighting the actual stage of the dispersed urban form development.

According to the accessibility and mobility issues identified in the analysis of the travel-related zones, the following improvements are suggested: - pedestrian zones

- developing the administrative sub-centers in the districts and thus creating a new urban form with multi-centers would bring the institutions, services and shopping locations closer to the living areas and offer the possibility to walk or cycle in this purpose

- transforming the brown fields located in the city centre fringe into housing areas would bring benefits for both the municipality and the new residents

- more pedestrianized areas in the city centre and better walking conditions for citizens and tourists

- more dedicated cycling infrastructure for better cycling commuting 
- more park \& ride facilities, which discourage the car access in the historical city center

- public transport zones

- the intensive public transport cells are mainly connected, forming corridors with few disruptions which could be improved by implementing few intermediate bus stations

- the good public transport cells are less connected on the basis of the unoptimized headways and unfitted location of the stops and thus improvements of the services on this line are necessary

- car-oriented zones - the large area was divided according to the housing characteristics as it follows:

- the dispersed car-oriented zones - defined by the poor or inexistent public transport services. In the areas where the public transport lines exist an optimized headway is needed. Furthermore the expansion of several existing lines and even promoting new lines are plausible measures. The poor infrastructure conditions don't offer real possibilities for walking and cycling

- the compact car-oriented zones - the cells fill out the gaps in the public transport corridors as a result of the inappropriate headway of the public transport and the remote of the stops. Therefore an optimized headway and intermediate stops are needed.

On the other hand, The Population Mobility Characteristics in ClujNapoca survey was recently conducted this year by means of internet survey. The sample population's daily travels database includes 785 people, of which 95\% of respondents live, and 5\% only work and study in Cluj-Napoca. The datasets include the respondents' personal characteristics - age group, sex, employment, address, and the total number of trips made in a $24 \mathrm{~h}$ period in the middle of the week with following details specified - trip purpose and location, travel time and starting time, main mode of transport - for all trips. Details regarding the motorized transport modes are also available: for car trips - driver or passenger, and for public transport - number of transfers, mean of transport and ticketing. An open-ended question about the respondents' opinion on the urban transportation was introduced in the final part and 30\% of respondents presented general and punctual insufficiencies encountered in the urban transport system in Cluj-Napoca. In general, all users of the urban transportation in Cluj-Napoca complained about the traffic management and especially the timing of the traffic lights, the improper infrastructure conditions, the parking system and the behavior of other participants in traffic. 
Considering the convergence of the reported problems we conclude that first a better parking control is necessary. Furthermore a systemic approach of all transport modes users is needed when the urban transportation development is assessed in the planning process. A real delimitation of the cycling paths and finalizing the major project the local government started is the right approach for ensuring the safe cycling in Cluj-Napoca. The condition of the sidewalks in the residential areas and more dedicated areas, especially in the city centre, are essential improvements. A further study for a more fitted design of the public transport lines is vital. Higher quality of the public transport services such as less crowded vehicles for the passengers and more comfort is also needed.

The zoning and the travel survey results were juxtaposed. The data was aggregated for the urban districts in order to create a more comprehensive outcome on the travel demand and modal choices in Cluj-Napoca, as well as on the accessibility to all modes. Thus strengthening the public transport corridors provides a viable alternative for the population to shift from the car use. An untargeted segment of the population living in the public transport zones was identified as an additional users-budget for the public transport. The location of the railway in the car-oriented zones was identified as a viable alternative to be developed for the commuters living nearby. Furthermore improving the walking and cycling dedicated areas present sustainable possibilities for the commuting on certain distances. But when all the scenarios for the improved urban mobility in Cluj-Napoca were analyzes a more complex outcome was obtained as illustrated in figure 7. Based on the travel-related zones' main mode of mobility, it was concluded that the more sustainable the mode is, the smaller area it serves. Thus the short and the long distances have to be considered distinctively for the urban mobility improvement. On the other hand, the more benign mobility is available the less investment is needed. Thus the future developments of housing, institutions, services, shopping centers, etc., could be located more properly according to the mobility availability in order to attain a smart urban development with smaller investment needs. 


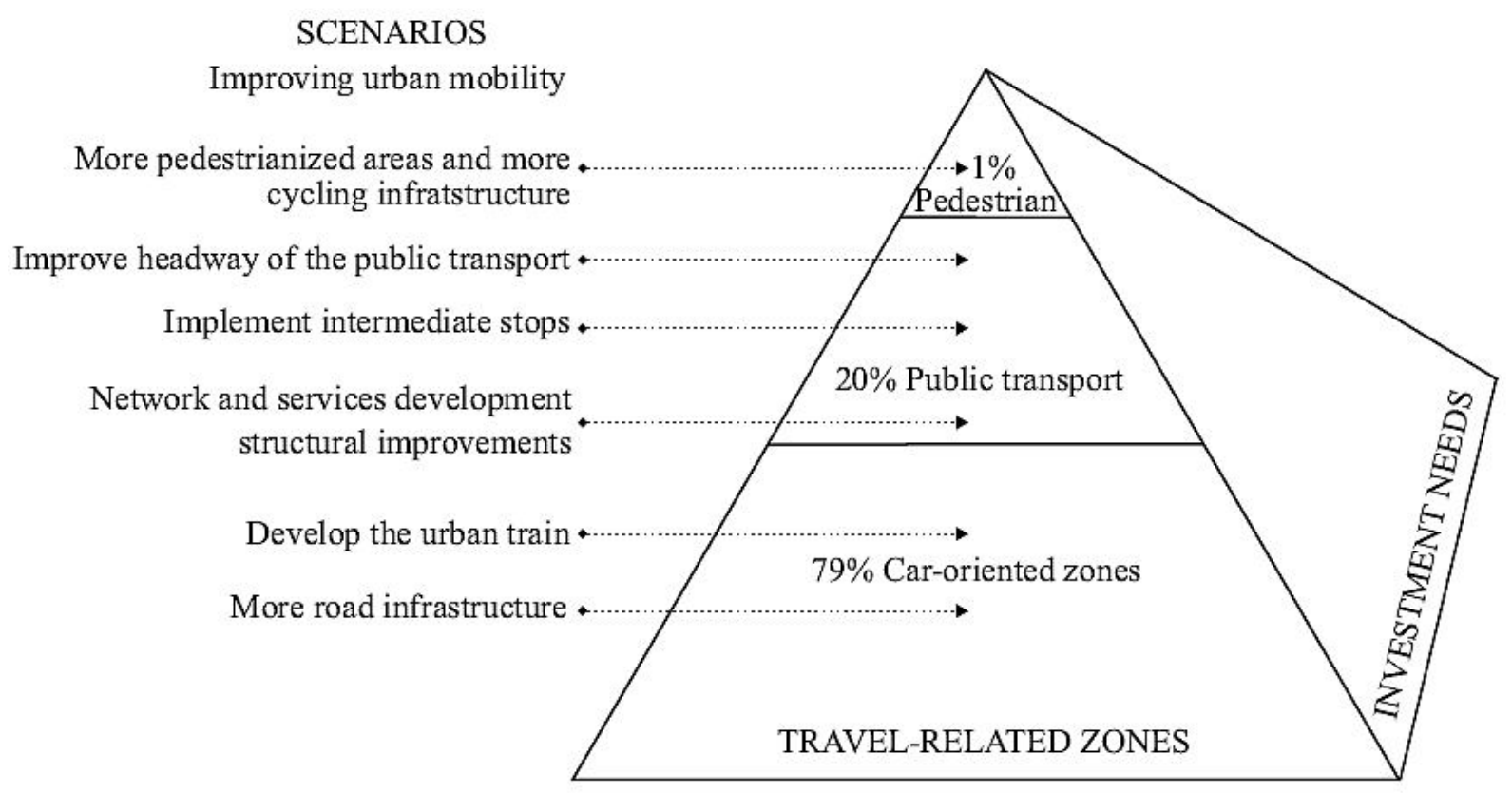

Figure 7. The analysis of the urban mobility improvement

\section{CONCLUSIONS}

The integrated analysis developed in this paper represents a useful tool for the planning process, for both the present and future urban development trends, in order to provide the effective urban fabric. For example new residential areas should be established into the public transport zone and so forth. The scenarios for the mobility improvement were developed for the city of Cluj-Napoca as an example here. Considering the systemic approach of the analysis towards a smart urban development that was presented in this article we conclude that the sustainable urban development can be achieved by using this tool in the planning process.

\section{ACKNOWLEDGEMENT}

"This research was supported by European Social Fund's Doctoral Studies and Internationalisation Programme DoRa, which is carried out by Foundation Archimedes." 


\section{REFERENCES}

[1]. ANTSO IMRE, ANTOV DAGO, MÄE, ROLAND, "Settlement changes effect to mobility in suburban area of Tallinn". In Ecology \& Safety. $22^{\text {nd }}$ International Symposium. ISSN: 1313-2563 7-11, 2013, Bulgaria.

[2]. BOITOR ROZALIA, ANTOV DAGO, ANTSO IMRE, ILIESCU MIHAI, "Analyzing the transportation accessibility for the city of Cluj-Napoca, a sustainable approach". In Ecology \& Safety, 22 ${ }^{\text {nd }}$ International Symposium. ISSN: 1313-2563 7-11, 2013, Bulgaria.

[3]. BOITOR ROZALIA, M., KUSZALIK JOZSEF , ANTOV DAGO, ILIESCU MIHAI, "Determining the population data in the transport planning process" In Materials and technologies in the construction and maintenance of roads and bridges and Traffic Safety Symposium, Cluj-Napoca, 2013. ISSN 2069-749X. (in Romanian)

[4]. CITY HALL OF CLUJ-NAPOCA n.d, The Strategy of Development for the city of Cluj-Napoca, $\langle$ http://www.primariaclujnapoca.ro/doc/strategie/Strategia_Municipiului_Cluj_Napoca .pdf $>$

[5]. EUROPEAN COMMISSION, Green Paper: Towards a new culture for urban mobility Communication from the Commission to the Council and Parliament [COM(2007)55].

[6]. EUROPEAN PLATFORM ON MOBILITY MANAGEMENT. The EPOMM Modal Split Tool, 2011, <http://epomm.eu/tems/index.phtml>

[7]. KNOFLACHER, HERMANN. "Success and failures in urban transport planning in Europe—understanding the transport system." Sadhana 32.4 (2007): 293-307.

[8]. RATUC -Regia Autonoma de Transport Urban Calatori, n.d., <www.ratuc.ro>.

[9]. RISTIMÄKI, M., KALENOJA, H., \& TIITU, M., Travel-related zones of urban form - zone criteria, urban form statistical profiles, and travel habits (in Finnish). Publications of the Ministry of Transport and Communications 15/2011. Helsinki. 